\title{
Reorganization of Cholinergic Terminals in the Cerebral Cortex and Hippocampus in Transgenic Mice Carrying Mutated Presenilin-1 and Amyloid Precursor Protein Transgenes
}

\author{
Tak Pan Wong, ${ }^{1}$ Thomas Debeir, ${ }^{1}$ Karen Duff, ${ }^{2}$ and A. Claudio Cuello ${ }^{1}$ \\ ${ }^{1}$ Department of Pharmacology and Therapeutics, McGill University, Montreal, Quebec, Canada, H3G 1Y6, and ${ }^{2}$ Nathan \\ Kline Institute, Orangeburg, New York 10962
}

Cholinergic deficits are one of the most consistent neuropathological landmarks in Alzheimer's disease (AD). We have examined transgenic mouse models $\left(\mathrm{PS}_{\mathrm{M} 146 \mathrm{~L}}, \mathrm{APP}_{\mathrm{K} 670 \mathrm{~N}, \mathrm{M} 671 \mathrm{~L}}\right)$ and a doubly transgenic line $\left(\mathrm{APP}_{\mathrm{K} 67 \mathrm{ON}, \mathrm{M} 671 \mathrm{~L}}+\mathrm{PS}_{\mathrm{M} 146 \mathrm{~L}}\right)$ that overexpress mutated AD-related genes [presenilin-1 (PS1) and the amyloid precursor protein (APP)] to investigate the effect of AD-related gene overexpression and/or amyloidosis on cholinergic parameters.

The size of the basal forebrain cholinergic neurons and the pattern of cholinergic synapses in the hippocampus and cerebral cortex were revealed by immunohistochemical staining for choline acetyltransferase and the vesicular acetylcholine transporter, respectively. At the time point studied (8 months), no apparent changes in either the size or density of cholinergic synapses were found in the $P S 1_{M 146 L}$ mutant relative to the nontransgenic controls. However, the $\mathrm{APP}_{\mathrm{K} 670 \mathrm{~N}, \mathrm{M} 671 \mathrm{~L}}$ mutant showed a significant elevation in the density of cholinergic synapses in the frontal and parietal cortices. Most importantly, the double mutant $\left(\mathrm{APP}_{\mathrm{K} 67 \mathrm{ON}, \mathrm{M} 671 \mathrm{~L}}+\mathrm{PS}_{\mathrm{M} 146 \mathrm{~L}}\right)$, which had extensive amyloidosis, demonstrated a prominent diminution in the density of cholinergic synapses in the frontal cortex and a reduction in the size of these synapses in the frontal cortex and hippocampus. Nonetheless, no significant changes in the size of basal forebrain cholinergic neurons were observed in these three mutants. This study shows a novel role of APP and a synergistic effect of APP and PS1 that correlates with amyloid load on the reorganization of the cholinergic network in the cerebral cortex and hippocampus at the time point studied.

Key words: Alzheimer's disease; cholinergic synapse; amyloid precursor protein; presenilin-1; transgenic mice; vesicular acetylcholine transporter
One of the most important neuropathological landmarks of Alzheimer's disease (AD) is the development of CNS cholinergic deficits (Bowen et al., 1976; Davies and Maloney, 1976). Such deficits are known to correlate with increased cognitive impairments (Perry et al., 1978; Collerton, 1986; DeKosky et al., 1992) and might be the result of death or atrophy of basal forebrain cholinergic neurons (Perry et al., 1978; Whitehouse et al., 1982; Pearson et al., 1983; Katzman, 1986).

Mutations in three genes have been shown to give rise to autosomal dominant familial Alzheimer's disease (FAD) (for review, see Price and Sisodia, 1998). These genes include presenilin-1 (PS1), (Sherrington et al., 1995), presenilin-2 (PS2) (Levy-Lahad et al., 1995), and the amyloid precursor protein

Received Sept. 23, 1998; revised Dec. 10, 1998; accepted Jan. 16, 1999.

This research was supported by grants from the National Institute on Aging and Medical Research Council to A.C.C. (National Institutes of Health \#AG-11903; MRC \#MT-14494) and K.D. (National Institutes of Health \#AG-146133). We thank SmithKline Beecham (Canada) for a grant on Structural/Functional Modeling and Imaging, Dr. Karen Hsiao (University of Minnesota) for the provision of the $\mathrm{APP}_{\mathrm{K} 670 \mathrm{~N}, \mathrm{M} 671 \mathrm{~L}}$ and the doubly transgenic line $\left(\mathrm{APP}_{\mathrm{K} 670 \mathrm{~N}, \mathrm{M} 671 \mathrm{~L}}+\mathrm{PS}_{\mathrm{M} 146 \mathrm{~L}}\right)$, and Dr. R. H. Edwards (University of California at San Francisco) for the generous gift of anti-vesicular acetylcholine transporter antibodies. We also thank Mr. Sheung Yee Shing for his excellent assistance in image analysis throughout the study; Sylvain Côté for perfusing and blind-coding the animals; Ms. Sue Grant and Dr. Linsen $\mathrm{Hu}$ for their valuable advice; Dr. Paul B. S. Clarke and Dr. Yves De Koninck for their suggestions on statistical analyses; Adriana Ducatenzeiler for her expert technical assistance; and Ms. Sunny Sanders and Xin Yu for mouse husbandry. T.P.W. is a recipient of the Croucher Foundation Scholarship (Hong Kong).

Correspondence should be addressed to Dr. A. Claudio Cuello, Department of Pharmacology and Therapeutics, McGill University, Montreal, Quebec, Canada, H3G 1 Y6.

Copyright (ㄷ) 1999 Society for Neuroscience $\quad 0270-6474 / 99 / 192706-11 \$ 05.00 / 0$
(APP) (for review, see Selkoe, 1994). These mutations have been shown to alter APP metabolism and to lead to an increase of the amyloid- $\beta$ protein $(\mathrm{A} \beta)$ peptide level in the brain. Pathogenic mutations in APP (such as $\mathrm{APP}_{\mathrm{K} 670 \mathrm{~N}, \mathrm{M} 671 \mathrm{~L}}$ ) either affect the $\mathrm{N}$-terminal ( $\beta$-secretase) cleavage site of the $\mathrm{A} \beta$ domain in APP, leading to elevated levels of $A \beta 1-40$ and $A \beta 1-42(43)$, or they affect the $\mathrm{C}$-terminal ( $\gamma$-secretase) cleavage site, leading to the elevation of A $\beta 1-42(43)$ specifically (Cai et al., 1993; Suzuki et al., 1994; Citron et al., 1992). Mutations in PS1 (such as $\left.\mathrm{PS}_{\mathrm{M} 146 \mathrm{~L}}\right)$ all lead to the elevation of $\mathrm{A} \beta 1-42(43)$ only, by an unknown mechanism (Borchelt et al., 1996; Duff et al., 1996; Scheuner et al., 1996; Citron et al., 1997).

Transgenic mice overexpressing mutated APP show greatly elevated levels of $A \beta$ and develop neuritic amyloid deposits that are highly reminiscent of the senile plaques in human AD brains (Games et al., 1995; Hsiao et al., 1996; Masliah et al., 1996; Nalbantoglu et al., 1997; Sturchler-Pierrat et al., 1997). Mice overexpressing mutated PS1 only have a small elevation in A $\beta 42(43)$ levels and do not show overt AD-like pathology (Duff et al., 1996; Citron et al., 1997). Interestingly, coexpression of mutated APP and PS1 genes has been shown to accelerate the accumulation of amyloid into extracellular deposits so that APP/ PS1 mice develop pathology several months before their singly transgenic APP littermates (Borchelt et al., 1997; Holcomb et al., 1998).

A recent report showed that APP mutants with extensive amyloidosis display dystrophic cholinergic fibers in the vicinity of neuritic plaques (Sturchler-Pierrat et al., 1997) and cell losses in the hippocampus (Calhoun et al., 1998). However, the involve- 

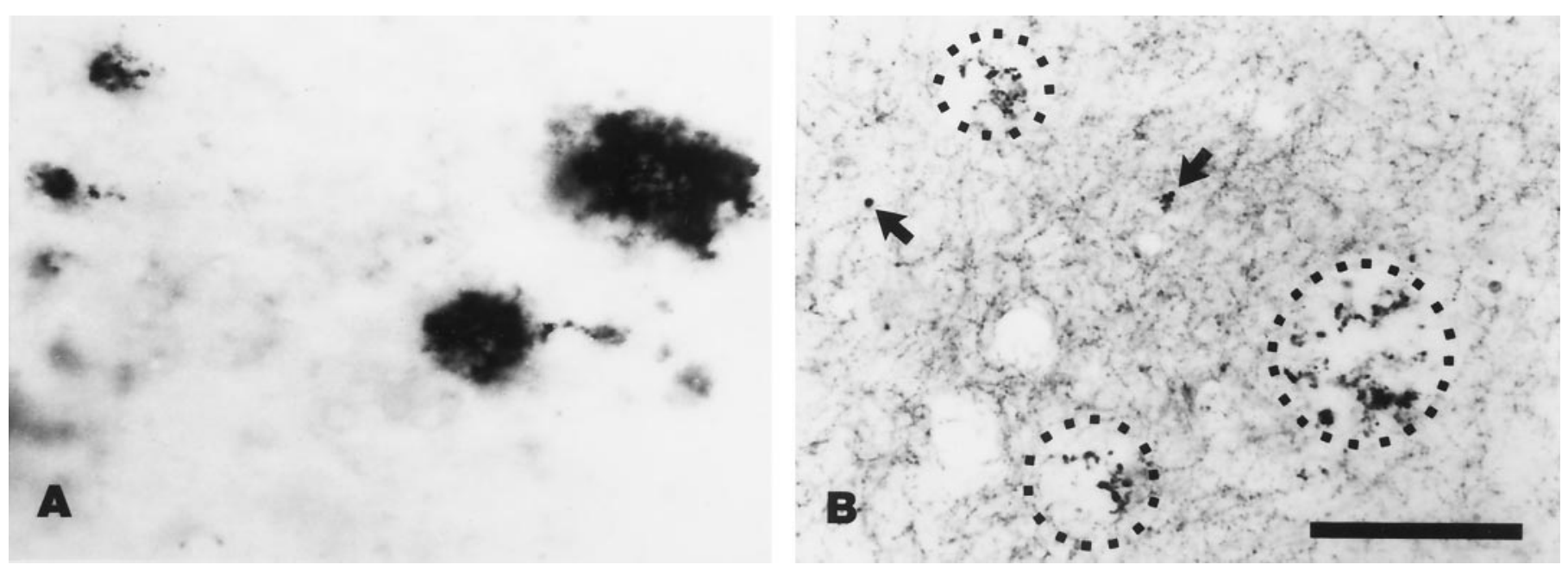

Figure 1. Light microscopical representations of $\mathrm{A} \beta$ aggregations and cholinergic distrophic dendrites in doubly transgenic mice. $A$, $\mathrm{A} \beta$ aggregations were present across different regions of the cerebral cortex and hippocampus. This micrograph depicts a typical plaque-like $A \beta$ aggregation in the cerebral cortex from a doubly transgenic $\left(\mathrm{APP}_{\mathrm{K} 670 \mathrm{~N}, \mathrm{M} 671 \mathrm{~L}}+\mathrm{PS}_{\mathrm{M} 146 \mathrm{~L}}\right)$ mouse. $B$, VAChT-IR cholinergic grossly distrophic neurites concentrated around a plaque. Some enlarged cholinergic boutons can be found in the remaining neuropile (arrowheads). Scale bar, $100 \mu \mathrm{m}$.

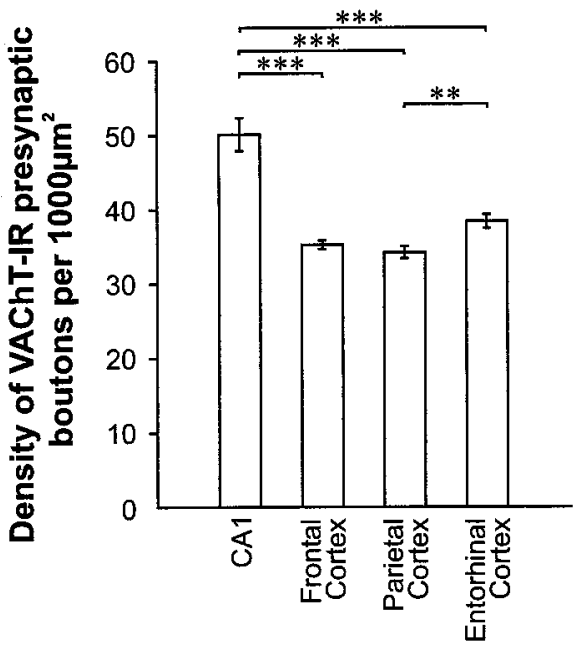

ment of mutated PS1 in the development of synaptic and cholinergic pathologies or the effect of mutated APP overexpression in the absence of amyloidosis has yet to be reported. To quantitatively investigate the effects of expressing mutated human APP and PS1 genes, alone or combined, on the cholinergic system, we have examined the steady state number of cholinergic presynaptic elements in the cerebral cortex and hippocampus in three types of transgenic mice. They include an APP mutant $\left(\mathrm{APP}_{\mathrm{K} 670 \mathrm{~N}, \mathrm{M} 671 \mathrm{~L}}\right.$, Hsiao et al., 1996), a PS1 mutant (PS1 ${ }_{\mathrm{M} 146 \mathrm{~L}}$, Duff et al., 1996), and a doubly transgenic line resulted from a cross between these two mutants $\left(\mathrm{APP}_{\mathrm{K} 670 \mathrm{~N}, \mathrm{M} 671 \mathrm{~L}}+\mathrm{PS} 1_{\mathrm{M} 146 \mathrm{~L}}\right.$, Holcomb et al., 1998).

\section{MATERIALS AND METHODS}

Perfusion and fixation. Animals used in the study were 8 months old and included mutated APP $\left(\mathrm{APP}_{\mathrm{K} 670 \mathrm{~N}, \mathrm{M} 671 \mathrm{~L}}\right)$ transgenic mice (derived from line Tg2576; $n=6)$, mutated PS1 (PS1 $\left.1_{\mathrm{M} 146 \mathrm{~L}}\right)$ transgenic mice $(n=7)$, doubly transgenic mice $\left(\mathrm{F}_{1}\right.$ of $\left.\mathrm{Tg} 2576 \times \mathrm{PS}_{\mathrm{M} 146 \mathrm{~L}} ; n=5\right)$ and nontransgenic littermates $(n=5)$. All mice were anesthetized with Equithesin (2.5 ml/kg, i.p.) and injected with heparin (4 USP/kg, i.p.) before perfusion. Animals were perfused briefly through the heart with perfu- sion buffer (for composition, see Côté et al., 1993) containing 0.1\% sodium nitrite, followed by a fixative containing $3 \%$ paraformaldehyde, $0.1 \%$ glutaraldehyde, and $15 \%$ picric acids in $0.1 \mathrm{M}$ phosphate buffer (PB), $\mathrm{pH} \mathrm{7.4,} \mathrm{for} 30 \mathrm{~min}$. Brains were removed from their skulls and post-fixed in the same fixative for $3 \mathrm{hr}$ at room temperature, followed by $10 \%$ sucrose in $\mathrm{PB}$ at $4^{\circ} \mathrm{C}$ for $2 \mathrm{~d}$. After fixation, brains were coded to ensure unbiased processing and analysis. The brains were then cut into $50 \mu \mathrm{m}$ coronal sections with a sledge freezing microtome (Leitz) at $-20^{\circ} \mathrm{C}$, from bregma $1.40 \mathrm{~mm}$ to bregma $-3.40 \mathrm{~mm}$ (Franklin and Paxinos, 1997). Sections from the same brain were separated into four groups for Nissl staining $(0.3 \%$ cresyl violet) to identify different cortical laminae, and immunohistochemical staining of vesicular acetylcholine transporter (VAChT), choline acetyltransferase (ChAT), and A $\beta$. These semi-serial Nissl-stained sections were also used to estimate the volume of brains and the thickness of different cortical laminae in the frontal, parietal, and entorhinal cortices from all animals we used.

Immunohistochemical staining. Free-floating immunohistochemical staining was performed as previously described (Côté et al., 1993). Briefly, 0.01 M PBS with $0.2 \%$ Triton X-100 (PBS $+\mathrm{T}$ ) was used for washing and diluting immunoreagents throughout the experiments, and two PBS $+T$ washes were performed in between all antibodies incubations. Sections from the four genetic groups were processed simultaneously.

VAChT immunohistochemical staining was performed using an avi- 


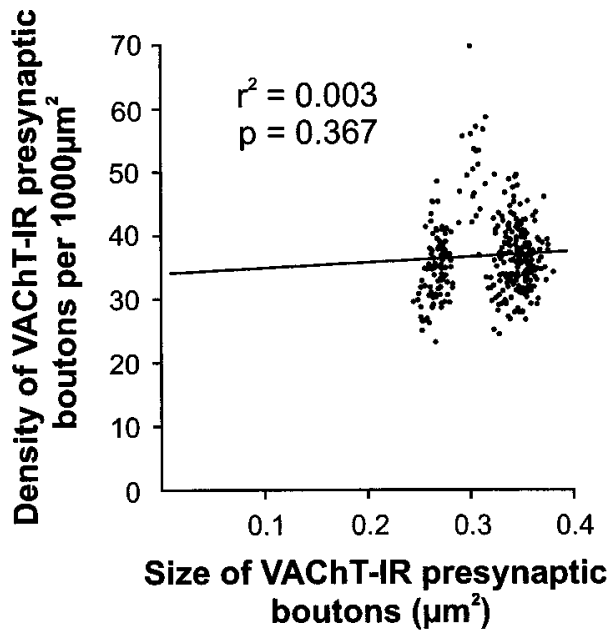

Figure 3. Variation in the density of VAChT-IR presynaptic boutons and the size of VAChT boutons. Observe the lack of correlation between the two variables $\left(r^{2}=0.003\right)$.

din-biotin complex method. Brain sections were treated with $0.1 \%$ sodium borohydride (Sigma, St. Louis, MO) in 0.01 m PBS for $30 \mathrm{~min}$, then incubated with $5 \%$ normal goat serum (Sigma) at $37^{\circ} \mathrm{C}$ for $30 \mathrm{~min}$. Normal goat serum $(2.5 \%)$ was added to all the solutions containing immunoreagents to further reduce the background. A polyclonal antiserum against VAChT (1:8000; a gift from Dr. R. H. Edwards) was used to identify presynaptic cholinergic sites. Sections were incubated with the antiserum solution for $48 \mathrm{hr}$ at $4^{\circ} \mathrm{C}$, followed by two $2 \mathrm{hr}$ subsequent incubations with biotinylated goat anti-rabbit antibody (1:500; Vector Laboratories, Burlingame, CA) and avidin-biotin complex (1:250; Vector) at room temperature. After treating with $0.6 \% \mathrm{DAB}, \mathrm{H}_{2} \mathrm{O}_{2}$ was added, and the reaction was continued for $4 \mathrm{~min}$.

Cholinergic neurons in both the medial septum and nucleus basalis magnocellularis (NBM) were labeled by ChAT immunohistochemical staining. After pretreating the sections with $0.3 \% \mathrm{H}_{2} \mathrm{O}_{2}$ for $30 \mathrm{~min}$ to reduce endogenous peroxidase activity, sections were incubated with a rat anti-ChAT monoclonal antibody (1:10; Boehringer Mannheim, Indianapolis, IN) overnight at $4^{\circ} \mathrm{C}$, followed by a $1 \mathrm{hr}$ incubation of goat anti-rat IgG (1:15; Sigma) and a $1 \mathrm{hr}$ incubation with monoclonal rat anti-peroxidase antibody (1:20; Medicorp; Cuello et al., 1984) containing $5 \mu \mathrm{g} / \mathrm{ml}$ horseradish peroxidase (Sigma, type IV) at room temperature. An intensified $\mathrm{DAB}$ reaction was performed by incubating the sections with $0.6 \% \mathrm{DAB}, 0.025 \% \mathrm{CoCl}_{2}$ (BDH Chemicals, Poole, UK), and $0.02 \% \mathrm{Ni}\left(\mathrm{NH}_{4}\right)_{2}\left(\mathrm{SO}_{4}\right)_{2}$ (BDH Chemicals) for $15 \mathrm{~min}$ at room temperature. $\mathrm{H}_{2} \mathrm{O}_{2}$ was subsequently added to the DAB solution, and the reaction was continued for $10 \mathrm{~min}$.

A mouse monoclonal antibody against A $\beta$ (Grant et al., 1997) was used to demonstrate $\mathrm{A} \beta$ aggregates in the transgenic mice. Before immunostaining, brain sections were incubated in $0.5 \% \mathrm{H}_{2} \mathrm{O}_{2}$ for $30 \mathrm{~min}$, followed by a treatment of $3 \%$ bovine serum albumin (Sigma) for $60 \mathrm{~min}$ at room temperature. Sections were then incubated with the mouse anti-A $\beta$ antibody $(1: 1500)$ overnight at $4^{\circ} \mathrm{C}$, followed by a $1 \mathrm{hr}$ incubation with goat anti-mouse IgG (1:50; ICN Biochemicals, Montréal, Québec, Canada) and a $1 \mathrm{hr}$ incubation with monoclonal mouse anti-peroxidase antibody (1:30; Medicorp; Semenenko et al., 1985) in the presence of 5 $\mu \mathrm{g} / \mathrm{ml}$ horseradish peroxidase (Sigma, type IV) at room temperature. After 15 min of DAB treatment, $\mathrm{H}_{2} \mathrm{O}_{2}$ was added, and the reaction was continued for $4 \mathrm{~min}$.

After immunostaining, all sections were mounted on gelatin-coated glass slides, air-dried, dehydrated in ascending concentrations of ethanol, cleared with xylene, and coverslipped with Entellan (Merck, Darmstadt, Germany).

Quantification of immunohistochemical staining. Quantification of the density of VAChT-IR presynaptic boutons was performed essentially as previously described (Wong et al., 1998). Briefly, a BH-2 Olympus microscope equipped with a $100 \times$ oil immersion plan achromatic objective, and a $10 \times$ projection lens was used. The microscope was equipped with a CCD video camera and was connected to the MCID-M4 image analysis system (Imaging Research Inc., St. Catharines, Ontario, Cana- da). Immunopositive punctae were detected by the image analysis system using software devised for silver grain counting. Measurements were done following the landmarks established by Franklin and Paxinos (1997): frontal cortex, bregma 0.26, next to the cingulum; parietal cortex, bregma $0.26,0.6 \mathrm{~mm}$ dorsal to the rhinal fissure; hippocampus, bregma $-2.30 \mathrm{~mm}$, stratum radiatum of the CA1 region; entorhinal cortex, bregma $-2.30 \mathrm{~mm}$, adjacent to the piriform cortex. In the middle of every cortical lamina from the different cortical areas of each mouse, nine 8500 $\mu \mathrm{m}^{2}$ fields were digitized from three consecutive sections. Background staining in all fields from each brain area $(\sim 250$ fields from hippocampus and $\sim 1000$ fields from each cortical regions) was normalized separately by the M3D module from the M4 system. This correction allowed us to use a single detection threshold for measuring the number of IR presynaptic boutons. Segmentation values were selected by trial and error, and values that provided the most accurate measurements when compared with the direct visual counting of punctae on the computer screen were chosen. Once the ideal thresholds for detection were found, these values were saved in the computer program and kept at the same level for all samples. All blood vessels were excluded in the measurements. Results were expressed as the number of presynaptic boutons $/ 1000 \mu \mathrm{m}^{2}$. In the cerebral cortex, equal numbers of fields were obtained from each cortical lamina during quantification. When calculating the global density of VAChT boutons in the cerebral cortex, the mean value of the VAChT bouton density from each cortical lamina was proportionally corrected by their percentage thickness, so as to even out the differences between thicker (e.g., lamina V) and thinner cortical lamina (e.g., lamina I). In addition, the size of VAChT boutons was also measured.

The size of ChAT-IR neurons in the NBM and medial septum were visualized and analyzed blindly in the same way as the presynaptic boutons, except that a $40 \times$ objective was used instead. For the analysis of the NBM, a total of six sections from the midbasalis were taken from each animal as previously described (Garofalo et al., 1992). These sections were chosen from the middle portion of the NBM region, with three random fields quantified for each level. The medial septum was identified on the basis of two anteroposterior anatomical landmarks: the meeting of the body of the corpus callosum at the midline marked the anterior boundary, and the midline crossing of the anterior commissure and the appearance of the fornix marked the posterior boundary. Six sections were used to analyze cell size in the medial septum. For both areas, only neurons with a clear nucleus were measured.

After completing all quantification, the identity of each mouse was unveiled for statistical analysis. Results are shown as mean \pm SEM. To compare the size and density of presynaptic boutons between different groups of mice, one-way ANOVA was used. Post hoc Dunnett's tests were used for pair-wise comparisons between control and different transgenic mice. Other pair-wise comparisons were performed using post hoc Tukey tests. The Pearson test of correlation was also used for studying the possible relationship between two different parameters. To compare the lamina distribution of VAChT bouton density between different groups of animals, a repeated measures ANOVA analysis was used. The level of significance was set as $p<0.05$.

\section{RESULTS}

At the 8 month time point examined in this study, only the doubly transgenic mice display obvious extracellular deposits of $\mathrm{A} \beta$ immunoreactive material (Fig. 1). The amyloid phenotype of the doubly transgenic animals has been described in full by McGowan et al. (1999). Briefly, they are very similar to the $\mathrm{A} \beta$ deposits found in the old parental Tg2576 mice (Hsiao et al., 1996), other APP transgenic lines (Games et al., 1995; Sturchler-Pierrat et al., 1997), and in the human AD brain (Iwatsubo et al., 1996). In the doubly transgenic animals, we also observed grossly distorted VAChT-IR neurites within the neuropile surrounding the plaques (Fig. 1). Staining of VAChT-IR associated material with thioflavin S confirmed that most plaques were composed of fibrillar material, colocalizing with $\mathrm{A} \beta$-IR sites (data not shown).

Figure 2 shows the density and the size of VAChT-IR presynaptic boutons in different brain regions of control mice $(n=5)$. One-way ANOVA showed significant differences in both the density $(p<0.00001$; df $=3 ; F=25.79)$ and the size $(p<$ 0.00001 ; df $=3 ; F=220.07)$ of VAChT boutons in these brain 


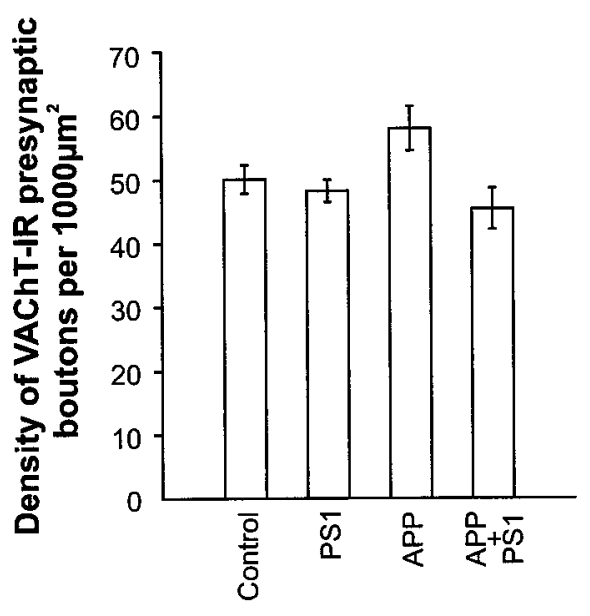

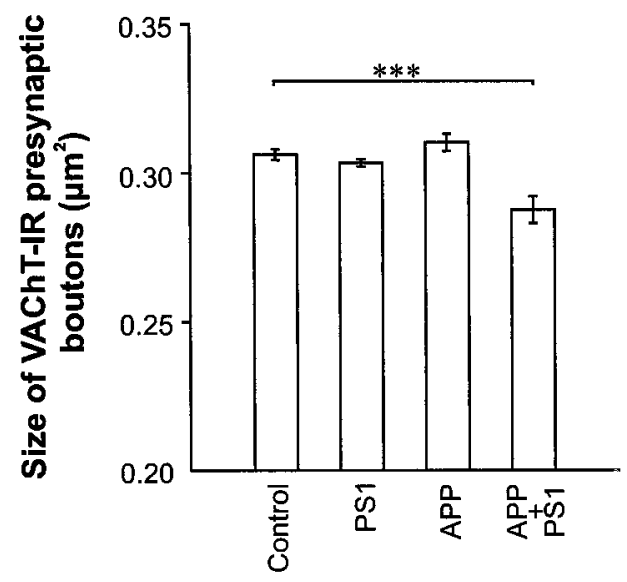

Figure 4. VAChT-IR presynaptic bouton density and size in the hippocampus of different transgenic mice. Data represent the mean \pm SEM. Statistically significant differences between animal groups could be found when comparing the density $(p<0.05)$ and the size $(p<0.05)$ of VAChT boutons. Pairwise comparison with control mice revealed only a significant reduction in the size of VAChT boutons of doubly transgenic mice $(* * * p<0.001)$.
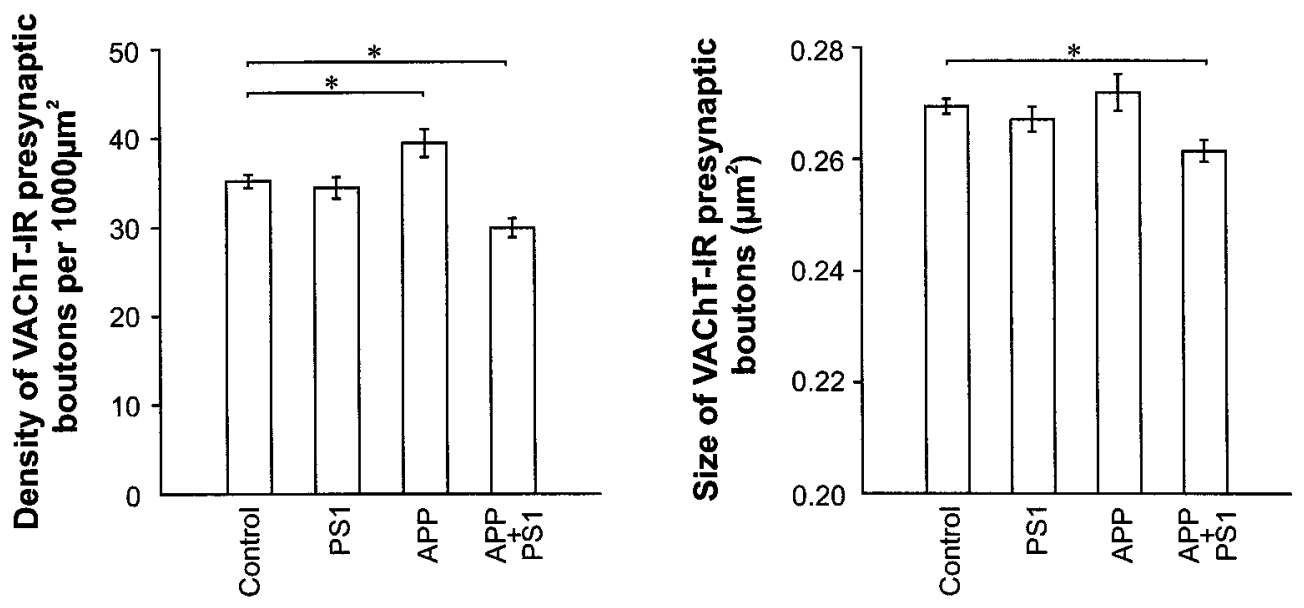

Figure 5. VAChT-IR presynaptic bouton density and size in the frontal cortex of different transgenic mice. A comparison of the global density (weighted mean from all cortical laminae) and the mean size of VAChT boutons between different transgenic mice revealed an elevated number in the $\mathrm{APP}_{\mathrm{K} 670 \mathrm{~N}, \mathrm{M} 671 \mathrm{~L}}$ transgenic line and a diminished number in the doubly transgenic line accompanied by shrunken bouton size $\left({ }^{*} p<\right.$ $0.05 ; * *<<0.01 ; * * * p<0.001)$. Data represent the mean \pm SEM.

regions. The present findings showed that the density of cholinergic innervation/1000 $\mu \mathrm{m}^{2}$ is highest in the hippocampus $(50.10 \pm 2.22)$, followed by the entorhinal cortex $(38.41 \pm 0.95)$, and lowest in the frontal $(35.25 \pm 0.60)$ and parietal cortices (34.23 \pm 0.82$)$. This distribution is comparable to the previous findings using acetylcholinesterase as the cholinergic marker (Mesulam et al., 1986). In addition, we have demonstrated that the size of cholinergic synapses was significantly different between the different brain regions studied. Both the parietal $(0.34$ $\left.\mu \mathrm{m}^{2} \pm 0.0027\right)$ and entorhinal cortices $\left(0.34 \mu \mathrm{m}^{2} \pm 0.0024\right)$ displayed the largest cholinergic synapses, followed by those in the hippocampus $\left(0.31 \mu \mathrm{m}^{2} \pm 0.0018\right)$. The smallest cholinergic synapses were found in the frontal cortex $\left(0.27 \mu \mathrm{m}^{2} \pm 0.0011\right)$. Because size differences between VAChT boutons may affect the detection of these immunoreactive elements by the image analysis system, correlation analysis was performed to see whether there is a positive correlation between the size and the density of the VAChT boutons. No correlation between the density and size of VAChT boutons in four different brain areas $\left(r^{2}=0.003\right.$; Fig. 3$)$ was found, demonstrating that the change in the density of VAChT boutons was not caused by the size variation between them. These data showed that VAChT-IR elements could accurately represent the cholinergic innervation in these brain areas. Finally, analyses of the brain volume between different mice groups showed no statistical differences (data not shown). Therefore, the quantitative methodology used in this study accurately reflects the changes in the density and size of cholinergic synapses after AD-related transgenes expression. Comparisons of the density and the size of VAChT boutons in different brain areas were next performed.

\section{$\mathrm{PS}_{\mathrm{M} 146 \mathrm{~L}}$ transgenic mice displayed no modification in cholinergic innervation}

No significant differences between the $\mathrm{PS}_{\mathrm{M} 146 \mathrm{~L}}$ transgenic mice and the control mice were found for the global density of VAChT boutons in the hippocampus (Fig. 4), the frontal cortex (Fig. 5), the parietal cortex (see Fig. 7), and the entorhinal cortex (see Fig. 8). Also, the detailed laminar comparison of VAChT bouton density in the frontal and parietal cortices between $\mathrm{PS} 1_{\mathrm{M} 146 \mathrm{~L}}$ transgenic mice and control mice did not reveal significant differences (Fig. 6). Furthermore, no changes in the size of VAChT boutons in $\mathrm{PS}_{\mathrm{M} 146 \mathrm{~L}}$ transgenic mice were found when compared with controls (Figs. 4-8). In fact, $\mathrm{PS}_{\mathrm{M} 146 \mathrm{~L}}$ transgenic mice displayed a similar laminar distribution of VAChT bouton density in both the frontal and parietal cortices when compared with controls (see Fig. 9).

\section{APP mutants displayed upregulation of cholinergic innervation}

APP transgenic mice without overt amyloid deposits displayed a significant increase in VAChT bouton density in the frontal $(p<$ 0.05 ; Fig. 5) and parietal cortices ( $p<0.01$; Fig. 7). In the frontal cortex, this increase occurred significantly in lamina I $(p<0.05)$ and lamina VI $(p<0.05$; Fig. 6). In addition, a significant 
A
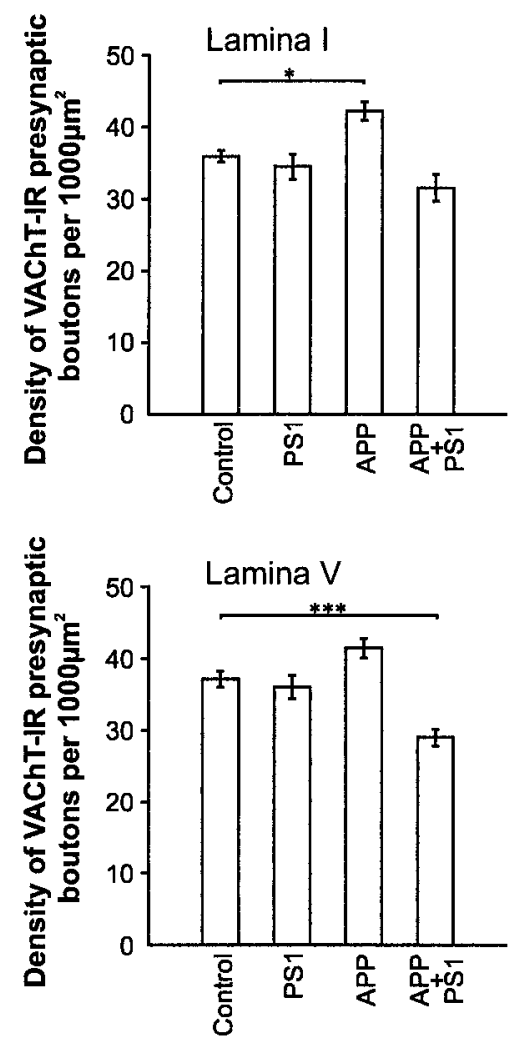

B

Figure 6. Density and size of VAChT boutons in different cortical laminae of the frontal cortex from different transgenic mice. $A$, Comparison to control mice revealed a statistically significant increase in the density of VAChT boutons in lamina I $(p<0.05)$ and lamina VI $(p<0.05)$ of $\mathrm{APP}_{\mathrm{K} 670 \mathrm{~N}, \mathrm{M} 671 \mathrm{~L}}$ transgenic mice. A similar comparison between control and doubly transgenic mice depicted a selective decrease in VAChT bouton density in lamina II, III $(p<0.001)$ and lamina $\mathrm{V}(p<$ $0.001)$. $B$, These decreases were accompanied by significantly smaller VAChT boutons in lamina I $(p<0.05)$, lamina II, III $(p<0.05)$, and lamina $\mathrm{V}(p<0.05)$. Note the different extent of changes in these two properties of cholinergic synapses across different cortical laminae $\left({ }^{*} p<0.05\right.$; $\left.{ }^{* *} p<0.01 ; * * p<0.001\right)$. Data represent the mean \pm SEM.
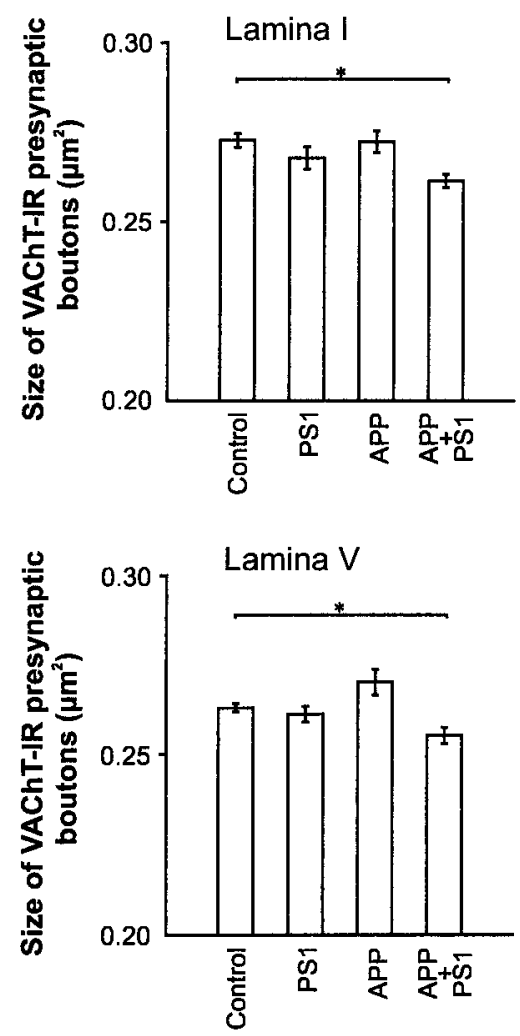
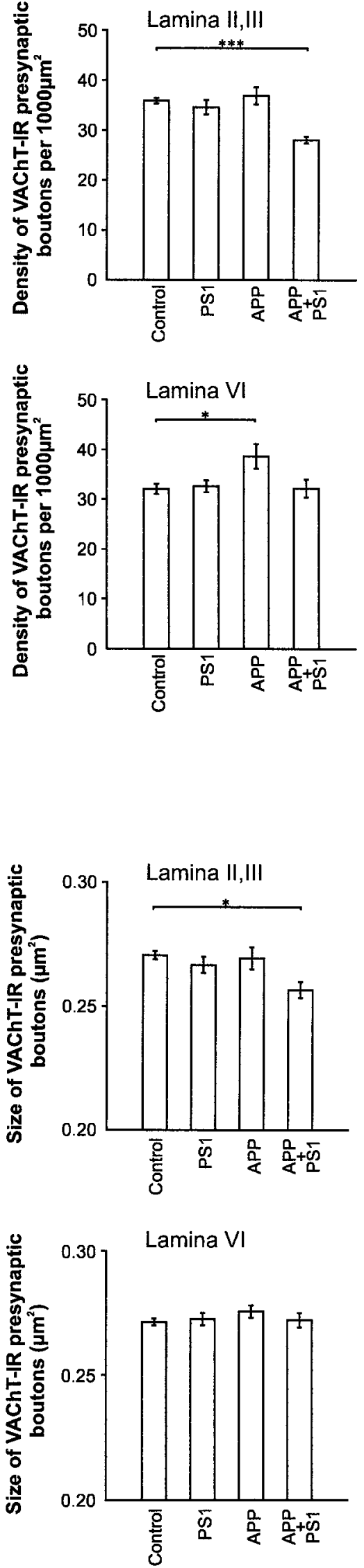

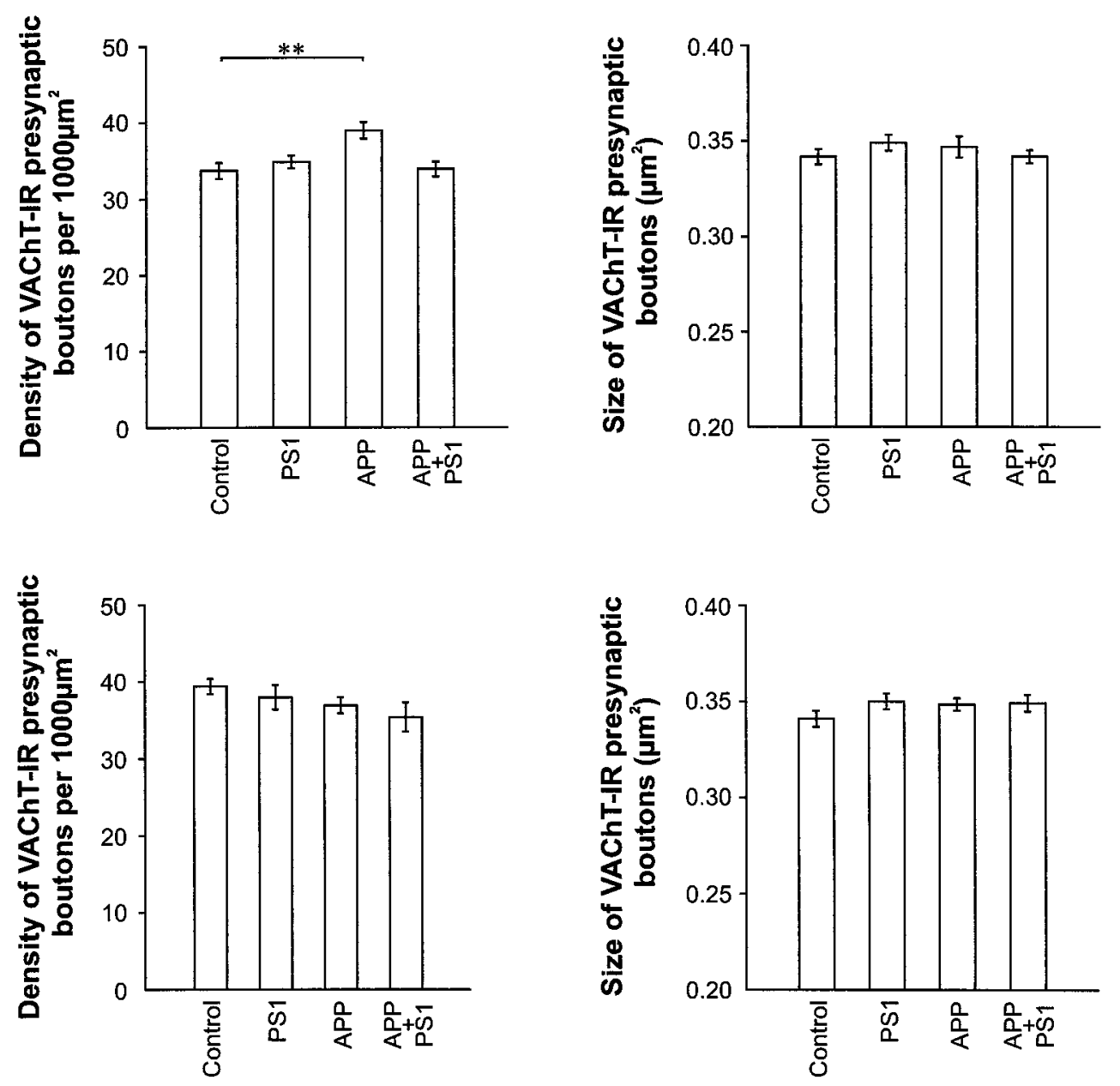

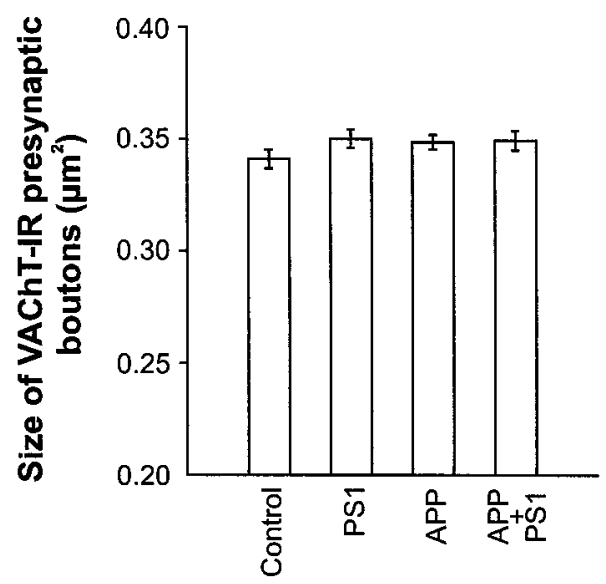

Figure 7. VAChT-IR presynaptic bouton density and size in the parietal cortex of different transgenic mice. Statistically significant differences between animal groups could be found when comparing the global density (weighted mean from all cortical laminae) of VAChT boutons $(p<0.01)$. Data represent the mean \pm SEM. Pair-wise comparison with control mice showed a significant elevation in VAChT bouton density in $\mathrm{APP}_{\mathrm{K} 670 \mathrm{~N}, \mathrm{M} 671 \mathrm{~L}}$ transgenic mice $(p<$ $0.01)$. No statistical differences were found when comparing VAChT bouton size between different mice groups.
Figure 8. VAChT-IR presynaptic bouton density and size in the entorhinal cortex of different transgenic mice. Data represent the mean \pm SEM. Observe the lack of a significant effect on cholinergic innervation after overexpression of different transgenes in this cortical area. increase in VAChT bouton density was found in lamina I $(p<$ $0.001)$, lamina II,III $(p<0.05)$, and lamina VI $(p<0.05)$ of the parietal cortex (data not shown). Thus, the increase in the cholinergic synapses in the cerebral cortex in response to expression of mutated human APP mainly occurred in the superficial (lamina I and II,III) and deep cortical laminae (lamina VI). A statistically nonsignificant increase in VAChT bouton density was also found in the hippocampus ( $p=0.08$; Fig. 4). Comparing the size of VAChT boutons in APP transgenic mice with control animals did not reveal any differences in any of the four brain areas.

\section{Doubly transgenic mice exhibited prominent cholinergic synaptic deficits}

Doubly transgenic mice showed a significant reduction in the density of VAChT boutons in the frontal cortex comparing with the control mice $(p<0.05$; Fig. 5). This reduction occurred selectively in lamina II,III $(p<0.001)$ and lamina V $(p<0.001$; Fig. 6). A similar, but not statistically significant, reduction in the density of VAChT boutons could also be found in the entorhinal cortex ( $p=0.10$; Figs. 8,9$)$. Although the global density of VAChT boutons in the parietal cortex from doubly transgenic mice was similar to that in controls, there were less VAChT punctae in lamina II,III in this cortical area $(p<0.05$; data not shown). Interestingly, the size of VAChT boutons in doubly transgenic mice was significantly smaller than controls in both the hippocampus ( $p<0.001$; Fig. 4$)$ and frontal cortex $(p<0.05$; Fig. 5). In the frontal cortex, significantly smaller VAChT boutons could be found in lamina I $(p<0.05)$, lamina II,III $(p<0.05)$, and lamina V ( $p<0.05$; Fig. 6). Despite these overall decreases in bouton size, we observed that many VAChT-IR boutons were large and distorted (Fig. 1). Figure 10 shows light microscopic micrographs demonstrating the changes in the cholinergic network of both the hippocampus and frontal cortex.

\section{Lack of evidence for cholinergic deficits in the entorhinal cortex}

The density of VAChT boutons in different mice groups analyzed by ANOVA showed significant differences in the hippocampus $(p<0.05 ; \mathrm{df}=3 ; F=3.81)$, the frontal cortex $(p<0.0005 ; \mathrm{df}=$ $3 ; F=10.38)$, and the parietal cortex $(p<0.005$; df $=3 ; F=$ 5.91). In addition, comparing the size of VAChT boutons between animal groups showed significant differences in the hippocampus $(p<0.005 ; \mathrm{df}=3 ; F=11.46)$ and the frontal cortex $(p<0.0005 ; \mathrm{df}=3 ; F=10.38)$. However, no differences in either the density or the size of VAChT boutons between these groups were found in the entorhinal cortex. Indeed, the laminar distributions of VAChT boutons in the entorhinal cortex of the different groups were similar after repeated measurements ANOVA ( $p=0.24$; df $=9 ; F=1.37$; Fig. 9). However, different laminar distributions of VAChT boutons in these groups were found in both the frontal $(p<0.001 ; \mathrm{df}=9 ; F=3.72)$ and parietal cortices $(p=0.06 ; \mathrm{df}=12 ; F=1,84)$. Because measurements of the thickness of these cortical regions revealed no difference between the groups (data not shown), these data show that transgene expression has subtle effects on the organization of cholinergic network in certain areas of the brain. 


\section{Frontal Cortex}

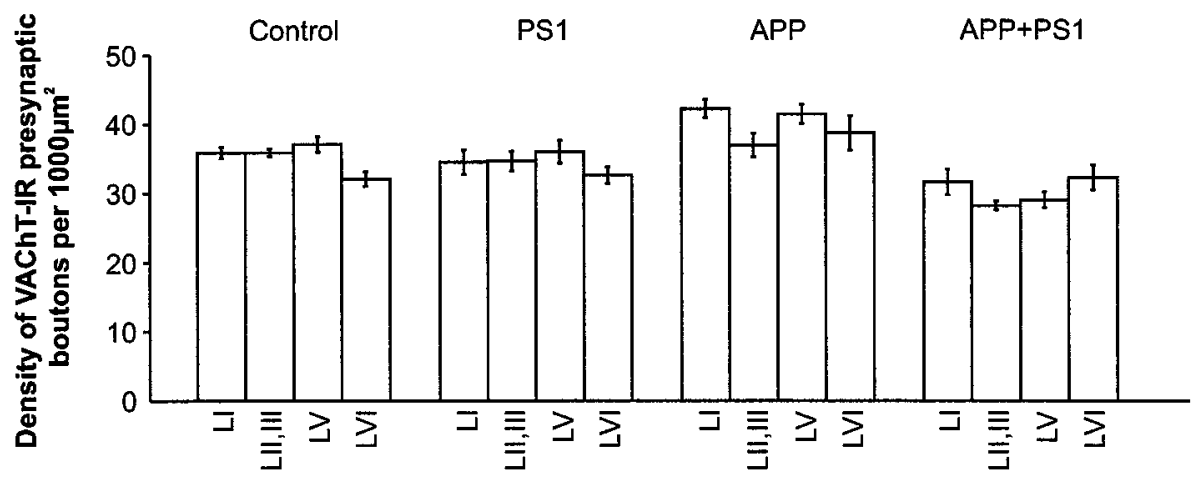

Cortical Laminae

\section{Parietal Cortex}

Figure 9. Illustration of the overall pattern of expressing $\mathrm{PS} 1_{\mathrm{M} 146 \mathrm{~L}}$, $\mathrm{APP}_{\mathrm{K} 670 \mathrm{~N}, \mathrm{M} 671 \mathrm{~L}}$, and $\mathrm{APP}_{\mathrm{K} 670 \mathrm{~N}, \mathrm{M} 671 \mathrm{~L}}+$ $\mathrm{PS} 1_{\mathrm{M} 146 \mathrm{~L}}$ transgenes on the laminar organization of the density of cholinergic synapses (VAChT-IR presynaptic boutons per $\left.1000 \mu \mathrm{m}^{2}\right)$. Data represent the mean \pm SEM. Results from repeated measurement ANOVA displayed a significant difference between mice groups when comparing the laminar organization of cholinergic synapses in the frontal cortex $(p<0.001)$, thus implying a significant reorganization of the cholinergic network after the expression of the human, mutated transgenes. Note the different patterns of cholinergic synaptic laminar distribution in $\mathrm{APP}_{\mathrm{K} 670 \mathrm{~N} \text { M671L }}$ and doubly transgenic mice, but not in the PS1 $1_{\mathrm{M} 146 \mathrm{~L}}$ transgenic mice, when compared with control mice. Less prominent changes $(p=0.06)$ were found in the parietal cortex, which could be caused by the prominent elevation in VAChT bouton density of $\mathrm{APP}_{\mathrm{K} 670 \mathrm{~N}, \mathrm{M} 671 \mathrm{~L}}$ transgenic mice. In contrast, the cholinergic synaptic laminar distribution in the entorhinal cortex of the different transgenic mice displayed similar patterns $(p=0.24)$ after repeated measurements ANOVA.

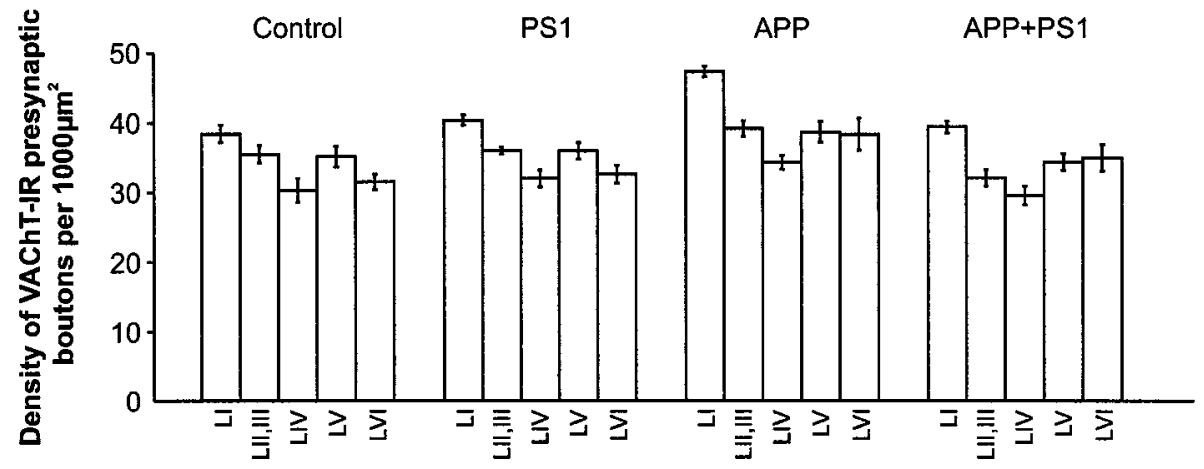

Cortical Laminae

\section{Entorhinal Cortex}

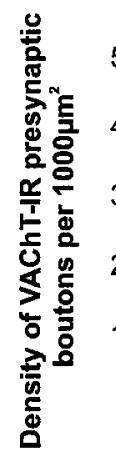

PS1

APP

APP+PS1
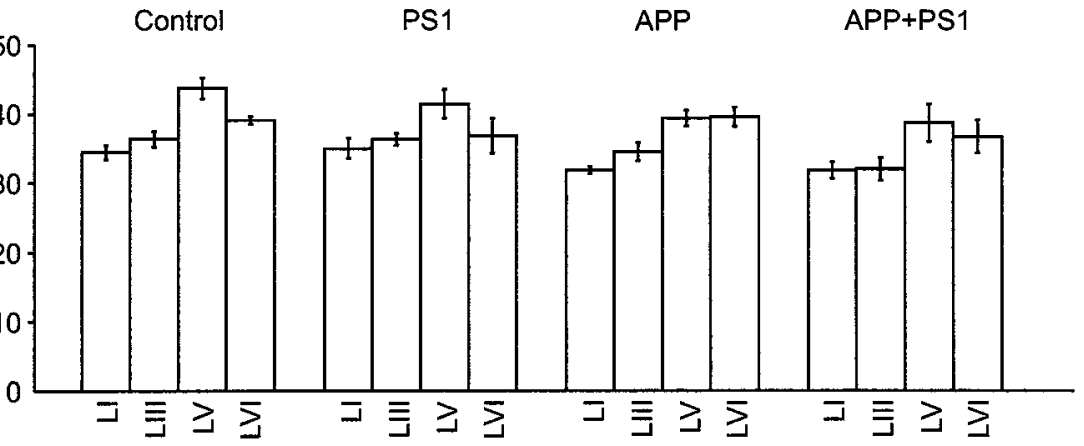

Cortical Laminae

\section{Local reorganization of cholinergic network without apparent modifications of the cell bodies of basal forebrain nuclei}

Although there were changes in the cholinergic innervation in the hippocampus and cerebral cortex, the sizes of cholinergic neurons from the medial septum and NBM were similar between different mice groups (Fig. 11). Indeed, results from ANOVA showed no significant difference in cell size from the medial septum $(p=$ 0.140 ; df $=3 ; F=2.048)$ and NBM $(p=0.74$; df $=3 ; F=0.419)$. An investigation of the possible relationship between the size of these cholinergic neurons and the density of the corresponding VAChT innervations showed no correlation between the septal cell size and VAChT density in the hippocampus $\left(r^{2}=0.002\right)$ and no correlation between the NBM cell size and VAChT density in the frontal cortex $\left(r^{2}=0.004\right)$.

\section{DISCUSSION}

We have found a rather complex interaction between the steady state number and size of cholinergic synapses in transgenic mice with different AD-related mutated transgenes and amyloid bur- 

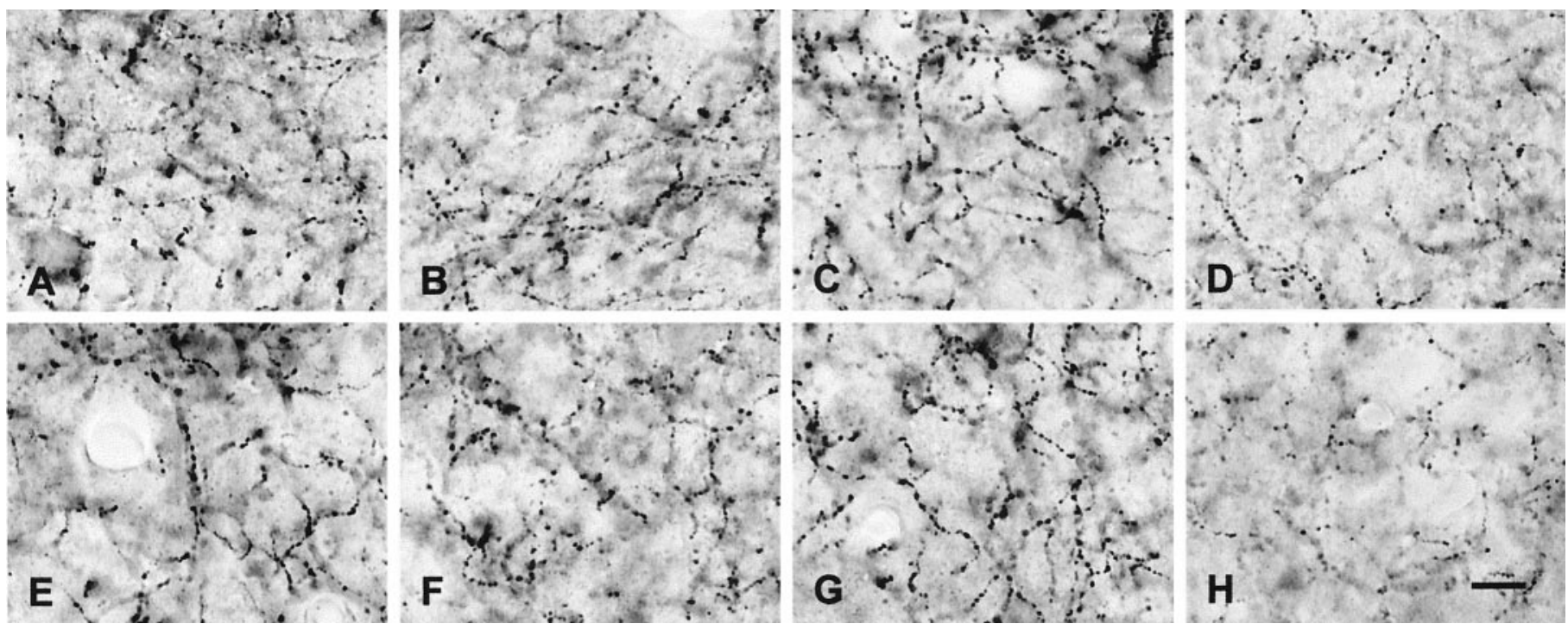

Figure 10. Light microscopic representation of VAChT-immunoreactive fibers and boutons in the hippocampus $(A-D)$ and in lamina V of frontal cortex $(E, F)$ from different transgenic mice groups. Note the similar density of VAChT-IR boutons in PS1 ${ }_{\mathrm{M} 146 \mathrm{~L}}$ transgenic mice $(B, F)$, elevated density of VAChT-IR boutons in APP $\mathrm{K} 670 \mathrm{~N}, \mathrm{M} 671 \mathrm{~L}_{\text {transgenic mice }}(C, G)$, and diminished density of VAChT-IR boutons in doubly transgenic mice $(D, H)$ when compared with control mice $(A, E)$. Observe also the significant decrease in the size of VAChT-IR in both the hippocampus and the frontal cortex of doubly transgenic mice $(D, H)$. Scale bar, $10 \mu \mathrm{m}$.

den. At the age investigated (8 months), expressing PS1 $1_{\mathrm{M} 146 \mathrm{~L}}$ alone had no effect on the density of cholinergic synapses. Unexpectedly, expressing $\mathrm{APP}_{\mathrm{K} 670 \mathrm{~N}, \mathrm{M} 671 \mathrm{~L}}$ only upregulated the density of cholinergic synapses in the frontal cortex, the parietal cortex, and the hippocampus. In contrast, expressing these two mutations together in doubly transgenic mice $\left(\mathrm{PS}_{\mathrm{M} 146 \mathrm{~L}}+\right.$ $\mathrm{APP}_{\mathrm{K} 670 \mathrm{~N}, \mathrm{M} 671 \mathrm{~L}}$ ) led to decreases in both the density and size of cholinergic synapses in the frontal cortex and hippocampus. Thus, it appears that some features of the double transgenic animal, which could include synergistic transgene interactions, elevated A $\beta 42(43)$ levels, or extensive amyloid deposition, are responsible for the cholinergic deficit.

In this study, we have used a relatively new cholinergic marker, VAChT, to label cholinergic terminals in different cortical regions. This protein has been shown to be a reliable and specific marker to identify cholinergic synapses. Colocalization of both the VAChT mRNA and the corresponding protein with the cholinergic marker, ChAT, has been substantiated (Gilmor et al., 1996). VAChT is therefore a more specific marker to reveal cholinergic networks than acetylcholinesterase, which has been shown to be present not only in cholinergic neurons, but also in cholinoceptive neurons (for review, see Butcher and Woolf, 1984).

Although knock-out studies have shown that PS1 has an important developmental role (Shen et al., 1997; Wong et al., 1997), the consequence of AD-linked mutations in PS1 is currently thought to be related to a gain-of-function activity on APP metabolism (Davis et al., 1998; Qian et al., 1998). Mutated PS1, but not wild-type, overexpression causes a $52 \%$ increase in the level of $\mathrm{A} \beta 42 / 43$ in $\mathrm{PS}_{\mathrm{M} 1461}$ mice (Duff et al., 1996). However, no deposition of $\mathrm{A} \beta$ or impaired performances in learning tests were reported in this mouse line (Holcomb et al., 1998). Parallel to these findings, we have shown that overexpressing $\mathrm{PS} 1_{\mathrm{M} 146 \mathrm{~L}}$ alone does not affect either the density or the size of the cholinergic synapses.

The increase in cholinergic synaptic density in $\mathrm{APP}_{\mathrm{K} 670 \mathrm{~N}, \mathrm{M} 671 \mathrm{~L}}$ transgenic mice was an unexpected finding, because $A \beta$ levels are known to be greatly elevated in the APP mice relative to PS1 and nontransgenic animals (Hsiao et al., 1996; Holcomb et al., 1998). Furthermore, APP mice at a similar age have been reported to show cognitive impairment in the spontaneous alternation paradigm (Hsiao et al., 1996; Holcomb et al., 1998; and unpublished data). The APP protein has however, been well documented to have trophic properties. Transgenic animals overexpressing other forms of mutated APP ( $\left.\mathrm{APP}_{\mathrm{C} 695 \mathrm{~T}}\right)$ also exhibited synaptogenesis in the frontal cortex (Mucke et al., 1994). Thus, overexpressing full length mutated APP in the mouse brain might not only increase the production of potentially toxic $\mathrm{A} \beta$ peptides but also the potential neurotrophic fragments of APP, such as the secreted region of APP. These neurotrophic fragments could lead to an upregulation of cholinergic synapses. Alternatively, these changes could be caused by the direct action of $\mathrm{A} \beta$ on cholinergic terminals. For instance, $A \beta 42$ or $A \beta 43$ peptides have been shown to potently inhibit the $\mathrm{K}^{+}$-evoked acetylcholine release from hippocampal slices, an effect that cannot be induced using scrambled, reverse, or all-D-isomer A $\beta$ sequences (Kar et al., 1996). In this scenario, the sustained inhibition of cholinergic synaptic functions might provoke, but not sustain, early compensatory changes or even sprouting of the cortical cholinergic network. Cognitive impairment induced by a reduction of cholinergic inputs can be corrected by increasing the production of acetylcholine in the terminal field of those inputs (Winkler et al., 1995). However, the observation that this transgenic line displayed cognitive deficits (Holcomb et al., 1998) might suggest an effective inhibitory effect of $\mathrm{A} \beta$ on the release of acetylcholine. Alternatively, the newly created cholinergic boutons could be aberrant and dysfunctional. Detailed time course studies of $\mathrm{A} \beta$ levels, amyloid aggregation status, and the cholinergic status in these transgenic lines will therefore be important to understand the significance of these reported changes in the terminal cholinergic network of the neocortex.

This is the first study to show that mutated $\mathrm{APP}_{\mathrm{K} 670 \mathrm{~N}, \mathrm{M} 671 \mathrm{~L}}$ acts synergistically with mutated $\mathrm{PS} 1_{\mathrm{M} 146 \mathrm{~L}}$ in eliciting cholinergic pathology. The decrease in cholinergic synaptic density was found 
A

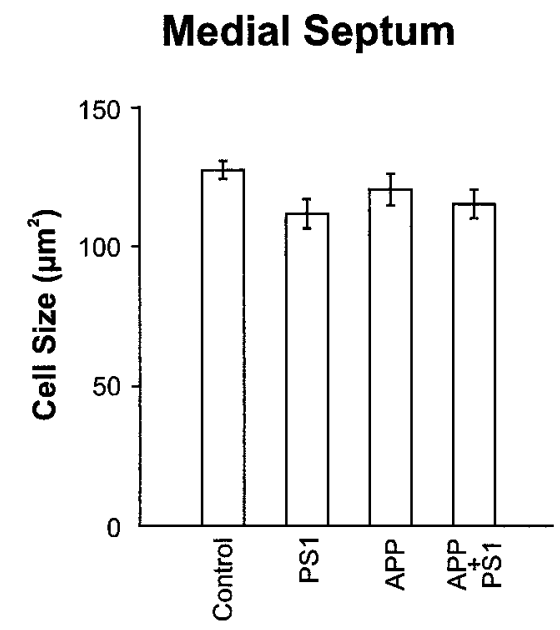

B

Figure 11. Cross-sectional areas of ChAT-IR neurons from the medial septum and NBM and the relationship of their size with VAChT-IR bouton density in the corresponding brain regions receiving their cholinergic inputs. Data represent the mean \pm SEM. $A$, Note the lack of significant difference between cholinergic cell size in the medial septum $(p=0.14)$ and the NBM $(p=0.74)$ in the different transgenic mice groups. $B$, No correlation between cholinergic cell size in the medial septum and NBM with the density of VAChT boutons in, respectively, the hippocampus $\left(r^{2}=0.002\right)$ and frontal cortex $\left(r^{2}=0.004\right)$ can be found.

to be more marked in the frontal cortex associated with an interesting decrease of their sizes. Furthermore, some cortical laminae actually showed a decrease in the size, but not in the density of cholinergic synapses (e.g., laminae $\mathrm{I}$ in the frontal cortex; Fig. 6). The widespread, regressive structural changes (shrinkage and loss of boutons) of the cortical cholinergic input would imply diminished function of the cholinergic system, an aspect that requires direct biochemical and electrophysiological confirmation. Because the cortical cholinergic network has been shown to be important in the development of memory (Winkler et al., 1995; Dykes, 1997; Tang et al., 1997; Sachdev et al., 1998) and seems to play an active role in the functional reorganization of the cortex after learning (Juliano et al., 1991; Kilgard and Merzenich, 1998), it is highly likely that the observed structural changes of cortical synapses contribute significantly to the behavioral impairments already observed in these transgenic mice (Hsiao et al., 1996; Holcomb et al., 1998).

Compared with the singly transgenic $\mathrm{APP}_{\mathrm{K} 670 \mathrm{~N}, \mathrm{M} 671 \mathrm{~L}}$ mice, the doubly transgenic mice display an earlier AD-like phenotype (Holcomb et al., 1998) that includes an increase in both A $\beta 1-40$ and 1-42 levels and the aggregation of $\mathrm{A} \beta$ into fibrils. Because overexpressing $\mathrm{APP}_{\mathrm{K} 670 \mathrm{~N}, \mathrm{M} 671 \mathrm{~L}}$ alone at this time point resulted in a completely opposite state in the cortical cholinergic network, and mutated PS1 overexpression alone had no effect, the accumulation or deposition of $\mathrm{A} \beta$ was though to play a crucial role in
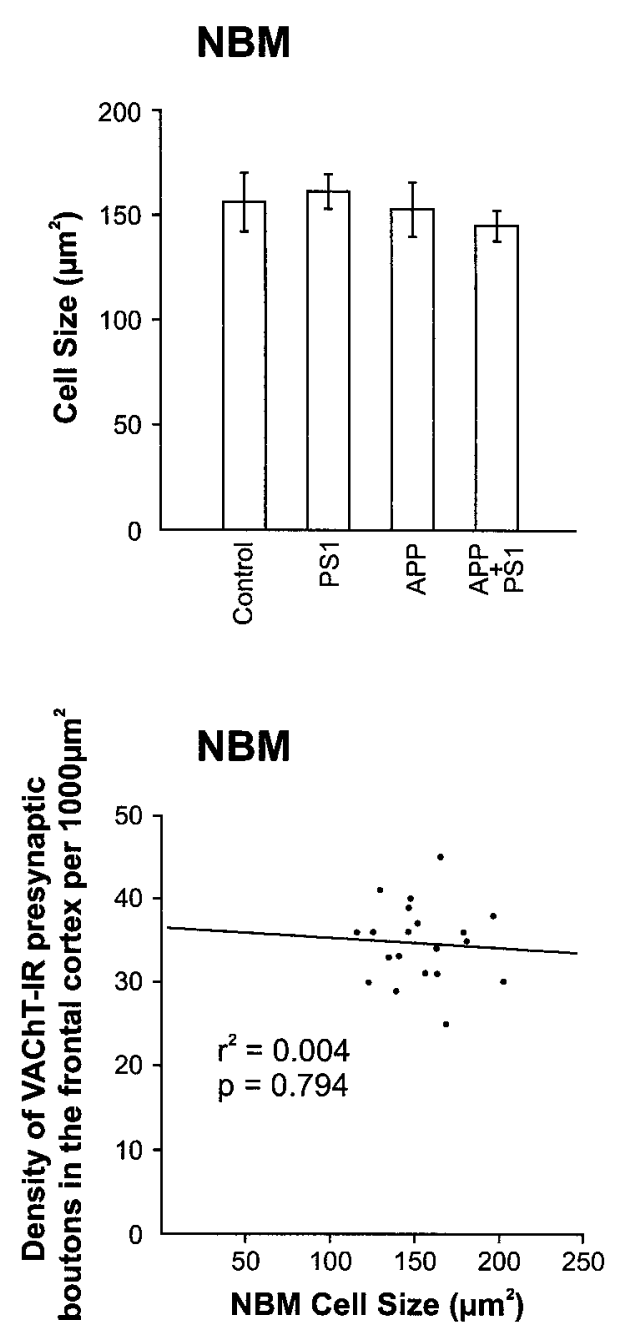

the establishment of cholinergic pathology in these transgenic lines and probably in human pathology. Whether this reflects intracellular accumulation of a soluble or fibrillar $\mathrm{A} \beta$ species or extracellular deposition could not be determined at this stage.

Although we have shown that cholinergic inputs to the cerebral cortex and hippocampus varies with the expression of different transgenes, changes in the size of the basal forebrain neurons were not found in any mouse at 8 months of age. This finding differs from studies on AD patients, which have shown that modification of the cholinergic inputs in the cortex is the result of either death or atrophy of the basal forebrain cholinergic neurons (Perry et al., 1978; Whitehouse et al., 1982; Pearson et al., 1983; Katzman, 1986). The lack of cell body atrophy could be related to the fact that massive loss of cerebral cortex tissue is required to provoke somatodendritic atrophy in the nucleus basalis (Sofroniew et al., 1983; Garofalo and Cuello, 1994). Therefore, a higher level of cortical pathology is required to elicit a retrograde involvement of the cholinergic basalocortical projection. Such a cholinergic atrophy, as found in $\mathrm{AD}$, has been previously proposed to be a secondary event to the cortical pathology (Cuello and Sofroniew, 1984). Furthermore, we have also observed a depletion of the cortical cholinergic synapses $(\sim 23 \%)$ after prolonged administration of NGF peptide mimetics acting as TrkA antagonists without noticeable change in the cell body size of nucleus basalis neurons (Debeir et al., 1998). We plan to examine 
these mice at later time points to establish whether basal forebrain cholinergic deficits develop later than cortical network deficits.

Apart from overall changes in the density of cholinergic synapses in different areas of the cortex, the laminar distribution of these synapses is also affected by mutated transgene expression. A significant change in laminar distribution of cholinergic synapses was found in the frontal cortex in $\mathrm{APP}_{\mathrm{K} 670 \mathrm{~N}, \mathrm{M} 671 \mathrm{~L}}$ and doubly transgenic mice $(p<0.05)$. In humans, a subtle differential laminar organization of cholinergic innervation has also been shown across regions of the cerebral cortex (Lysakowski et al., 1989). It is therefore possible that regional decreases in cholinergic innervation may have significant consequences for the learning process (Perry et al., 1984; DeKosky et al., 1985). Further studies are needed to unravel the significance of the laminar organization of cholinergic synapses in the cognitive performance of rodents and in the human species.

In humans, AD neurofibrillary pathology appears to commence in the entorhinal cortex, spreading into the hippocampus and isocortex (Braak et al., 1993; Braak and Braak, 1996). In doubly transgenic mice at 8 months of age, cholinergic pathology was found primarily in the frontal cortex and the hippocampus with little involvement of the entorhinal cortex. In situ studies on these animals (data not shown) have shown that the spread of amyloid deposition follows the expression pattern of the PS1 transgene, which is most prominently expressed in the cingulate cortex followed by the hippocampus. The correlation between cholinergic pathology in the frontal cortex and initial amyloid burden, with relative sparing of the entorhinal cortex, may explain the differential topography between the cholinergic pathology observed in humans and the AD-like animal models.

In conclusion, these studies illustrate that the expression of AD-related mutated genes in mice provokes profound modifications of cholinergic networks in different regions of the cerebral cortex and hippocampus. Expression of $\mathrm{PS}_{\mathrm{M} 146 \mathrm{~L}}$ alone did not induce cholinergic pathology. However, coexpression of $\mathrm{APP}_{\mathrm{K} 670 \mathrm{~N}, \mathrm{M} 671 \mathrm{~L}}$ and $\mathrm{PS}_{\mathrm{M} 146 \mathrm{~L}}$ induced a reduction in both the density and the size of cholinergic synapses in several cortical regions and hippocampus. Unexpectedly, the expression of $\mathrm{APP}_{\mathrm{K} 670 \mathrm{~N}, \mathrm{M} 671 \mathrm{~L}}$ alone resulted in an increase in the density of cholinergic synapses. Unlike the pathogenesis of human AD, the cholinergic inputs to both the entorhinal and parietal cortex were not significantly affected. These findings illustrate the complex relationship existing between the expression of mutated ADrelated genes, the resulting amyloid burden, and the pathogenesis of the cortical cholinergic network. Furthermore, these studies highlight the usefulness of transgenic mutants as viable animal models for the study of the synaptic and transmitter pathology known to be prominent in AD-related cognitive deficits.

\section{REFERENCES}

Borchelt DR, Thinakaran G, Eckman CB, Lee MK, Davenport F, Ratovitsky, Prada CM, Kim G, Seekins S, Yager D, Slunt HH, Wang R, Seeger M, Levey AI, Gandy SE, Copeland NG, Jenkins NA, Price DL, Younkin SG, Sisodia SS (1996) Familial Alzheimer's disease-linked presenilin 1 variants elevate Abeta1-42/1-40 ratio in vitro and in vivo. Neuron 17:1005-1013.

Borchelt DR, Ratovitski T, van Lare J, Lee MK, Gonzales V, Jenkins NA, Copeland NG, Price DL, Sisodia SS (1997) Accelerated amyloid deposition in the brains of transgenic mice coexpressing mutant presenilin 1 and amyloid precursor proteins. Neuron 19:939-945.

Bowen DM, Smith CB, White P, Davison AN (1976) Neurotransmitterrelated enzymes and indices of hypoxia in senile dementia and other abiotrophies. Brain 99:459-496.
Braak H, Braak E (1996) Evolution of the neuropathology of Alzheimer's disease. Acta Neurol Scand [Suppl]. 165:3-12.

Braak H, Braak E, Bohl J (1993) Staging of Alzheimer-related cortical destruction. Eur Neurol 33:403-408.

Butcher LL, Woolf NJ (1984) Histochemical distribution of acetylcholinesterase in the central nervous system: clues to the localization of cholinergic neurons. In: Classical transmitters and transmitter receptors in the CNS Part II (Bjorklund A, Hokfelt T, Kuhar MJ, eds), pp 1-50. Amsterdam: Elsevier Science.

Cai XD, Golde TE, Younkin SG (1993) Release of excess amyloid beta protein from a mutant amyloid beta protein precursor. Science 259:514-516.

Calhoun ME, Wiederhold KH, Abramowski D, Phinney AL, Probst A, Sturchler-Pierrat C, Staufenbiel M, Sommer B, Jucker M (1998) Neuron loss in APP transgenic mice. Nature 395:755-756.

Citron M, Oltersdorf T, Haass C, McConlogue L, Hung AY, Seubert P, Vigo-Pelfrey C, Lieberburg I, Selkoe DJ (1992) Mutation of the betaamyloid precursor protein in familial Alzheimer's disease increases beta-protein production. Nature 360:672-674.

Citron M, Westaway D, Xia W, Carlson G, Diehl T, Levesque G, Johnson-Wood K, Lee M, Seubert P, Davis A, Kholodenko D, Motter R, Sherrington R, Perry B, Yao H, Strome R, Lieberburg I, Rommens J, Kim S, Schenk D, Fraser P, St George H, Selkoe DJ (1997) Mutant presenilins of Alzheimer's disease increase production of 42-residue amyloid beta-protein in both transfected cells and transgenic mice. Nature Med 3:67-72.

Collerton D (1986) Cholinergic function and intellectual decline in Alzheimer's disease. Neuroscience 19:1-28.

Côté SL, Ribeiro-da-Silva A, Cuello AC (1993) Current protocols for light microscopy immunocytochemistry. In: Immunohistochemistry II (Cuello AC, ed), pp 147-168. West Sussex: Wiley.

Cuello AC, Sofroniew MV (1984) The anatomy of the CNS cholinergic neurons. Trends Neurosci 7:74-78.

Cuello AC, Milstein C, Wright B, Bramwell S, Priestley JV, Jarvis J (1984) Development and application of a monoclonal rat peroxidase antiperoxidase (PAP) immunocytochemical reagent. Histochemistry 80:257-261.

Davies P, Maloney AJ (1976) Selective loss of central cholinergic neurons in Alzheimer's disease. Lancet 2:1403.

Davis JA, Naruse S, Chen H, Eckman C, Younkin S, Price DL, Borchelt DR, Sisodia SS, Wong PC (1998) An Alzheimer's disease-linked PS1 variant rescues the developmental abnormalities of PS1-deficient embryos. Neuron 20:603-609.

Debeir T, Saragovi HU, Cuello AC (1998) TrkA antagonists decrease NGF-induced ChAT activity in vitro and modulate cholinergic synaptic number in vivo. J Physiol (Paris) 92:205-208.

DeKosky ST, Harbaugh RE, Schmitt FA, Bakay RA, Chui HC, Knopman DS, Reeder TM, Shetter AG, Senter HJ, Markesbery WR (1992) Cortical biopsy in Alzheimer's disease: diagnostic accuracy and neurochemical, neuropathological, and cognitive correlations. Intraventricular Bethanecol Study Group. Ann Neurol 32:625-632.

DeKosky ST, Scheff SW, Markesbery WR (1985) Laminar organization of cholinergic circuits in human frontal cortex in Alzheimer's disease and aging. Neurology 35:1425-1431.

Duff K, Eckman C, Zehr C, Yu X, Prada CM, Perez-tur J, Hutton M, Buee L, Harigaya Y, Yager D, Morgan D, Gordon MN, Holcomb L, Refolo, Zenk B, Hardy J, Younkin S (1996) Increased amyloidbeta42(43) in brains of mice expressing mutant presenilin 1 . Nature 383:710-713.

Dykes RW (1997) Mechanisms controlling neuronal plasticity in somatosensory cortex. Can J Physiol Pharmacol 75:535-545.

Franklin KBJ, Paxinos G (1997) The mouse brain in stereotaxic coordinates. San Diego: Academic.

Games D, Adams D, Alessandrini R, Barbour R, Berthelette P, Blackwell C, Carr T, Clemens J, Donaldson T, Gillespie F, Guido T, Hagoplan S, Johnson-Wood K, Khan K, Lee M, Leibowitz P, Lieberburg I, Little S, Masliah E, McConlogue L, Montoya-Zavala M, Mucke L, Paganini L, Penniman E, Power M, Schenk D, Seubert P, Snyder B, Soriano F, Tan H, Vitale J, Wadsworth S, Wolozin B, Zhao J (1995) Alzheimer-type neuropathology in transgenic mice overexpressing v717f beta-amyloid precursor protein. Nature 373:523-527.

Garofalo L, Cuello AC (1994) Nerve growth factor and the monosialoganglioside GM1: analogous and different in vivo effects on biochemical, morphological, and behavioral parameters of adult cortically lesioned rats. Exp Neurol 125:195-217. 
Garofalo L, Ribeiro-da-Silva A, Cuello AC (1992) Nerve growth factorinduced synaptogenesis and hypertrophy of cortical cholinergic terminals. Proc Natl Acad Sci USA 89:2639-2643.

Gilmor ML, Nash NR, Roghani A, Edwards RH, Yi H, Hersch SM, Levey AI (1996) Expression of the putative vesicular acetylcholine transporter in rat brain and localization in cholinergic synaptic vesicles. J Neurosci 16:2179-2190.

Grant SM, Szyf M, Cuello AC (1997) Ultrastructural localization of amyloid beta protein in transfected embryonal carcinoma (P19) cells after neuroectodermal differentiation. Soc Neurosci Abstr 23:540.

Holcomb L, Gordon MN, McGowan E, Yu X, Benkovic S, Jantzen P, Wright, Saad I, Mueller R, Morgan D, Sanders S, Zehr C, O'Campo K, Hardy, Prada CM, Eckman C, Younkin S, Hsiao K, Duff K (1998) Accelerated Alzheimer-type phenotype in transgenic mice carrying both mutant amyloid precursor protein and presenilin 1 transgenes. Nature Med 4:97-100.

Hsiao K, Chapman P, Nilsen S, Eckman C, Harigaya Y, Younkin S, Yang F, Cole G (1996) Correlative memory deficits, Abeta elevation, and amyloid plaques in transgenic mice. Science 274:99-102.

Iwatsubo T, Saido TC, Mann DM, Lee VM, Trojanowski JQ (1996) Full-length amyloid-beta (1-42(43)) and amino-terminally modified and truncated amyloid-beta $42(43)$ deposit in diffuse plaques. Am J Pathol 149:1823-1830.

Juliano SL, Ma W, Eslin D (1991) Cholinergic depletion prevents expansion of topographic maps in somatosensory cortex. Proc Natl Acad Sci USA 88:780-784.

Kar S, Seto D, Gaudreau P, Quirion R (1996) Beta-amyloid-related peptides inhibit potassium-evoked acetylcholine release from rat hippocampal slices. J Neurosci 16:1034-1040.

Katzman R (1986) Alzheimer's disease. N Engl J Med 314:964-973.

Kilgard MP, Merzenich MM (1998) Cortical map reorganization enabled by nucleus basalis activity. Science 279:1714-1718.

Levy-Lahad E, Wasco W, Poorkaj P, Romano DM, Oshima J, Pettingell WH, Yu CE, Jondro PD, Schmidt SD, Wang K (1995) Candidate gene for the chromosome 1 familial Alzheimer's disease locus. Science 269:973-977.

Lysakowski A, Wainer BH, Bruce G, Hersh LB (1989) An atlas of the regional and laminar distribution of choline acetyltransferase immunoreactivity in rat cerebral cortex. Neuroscience 28:291-336.

Masliah E, Sisk A, Mallory M, Mucke L, Schenk D, Games D (1996) Comparison of neurodegenerative pathology in transgenic mice overexpressing v717f beta-amyloid precursor protein and Alzheimer's disease. J Neurosci 16:5795-5811.

McGowan E, Sanders S, Iwatsubo T, Takeuchi A, Saido T, Zehr C, Yu X, Uljon SE, Wang R, Hsiao K, Mann D, Dickson D, Duff K (1999) Abnormal pathology development in transgenic mice over-expressing both mutant amyloid recursor protein and mutant presenilin-1 transgenes. Neurobiol Dis, in press.

Mesulam MM, Volicer L, Marquis JK, Mufson EJ, Green RC (1986) Systematic regional differences in the cholinergic innervation of the primate cerebral cortex: distribution of enzyme activities and some behavioral implications. Ann Neurol 19:144-151.

Mucke L, Masliah E, Johnson WB, Ruppe MD, Alford M, Rockenstein EM, Forss-Petter S, Pietropaolo M, Mallory M, Abraham CR (1994) Synaptotrophic effects of human amyloid beta protein precursors in the cortex of transgenic mice. Brain Res 666:151-167.

Nalbantoglu J, Tirado-Santiago G, Lahsaini A, Poirier J, Goncalves O, Verge G, Momoli F, Welner SA, Massicotte G, Julien JP, Shapiro ML (1997) Impaired learning and LTP in mice expressing the carboxy terminus of the Alzheimer amyloid precursor protein. Nature 387:500-505.

Pearson RC, Sofroniew MV, Cuello AC, Powell TP, Eckenstein F, Esiri MM, Wilcock GK (1983) Persistence of cholinergic neurons in the basal nucleus in a brain with senile dementia of the Alzheimer's type demonstrated by immunohistochemical staining for choline acetyltransferase. Brain Res 289:375-379.
Perry EK, Tomlinson BE, Blessed G, Bergmann K, Gibson PH, Perry RH (1978) Correlation of cholinergic abnormalities with senile plaques and mental test scores in senile dementia. Br Med J 2:1457-1459.

Perry EK, Atack JR, Perry RH, Hardy JA, Dodd PR, Edwardson JA, Blessed G, Tomlinson BE, Fairbairn AF (1984) Intralaminar neurochemical distributions in human midtemporal cortex: comparison between Alzheimer's disease and the normal. J Neurochem 42:1402-1410.

Price DL, Sisodia SS (1998) Mutant genes in familial Alzheimer'sdisease and transgenic models. Annu Rev Neurosci 21:479-505.

Qian S, Jiang P, Guan XM, Singh G, Trumbauer ME, Yu H, Chen HY, Van der Ploeg LH, de Ploeg LH, Zheng H (1998) Mutant human presenilin 1 protects presenilin 1 null mouse against embryonic lethality and elevates Abeta1-42/43 expression. Neuron 20:611-617.

Sachdev RN, Lu SM, Wiley RG, Ebner FF (1998) Role of the basal forebrain cholinergic projection in somatosensory cortical plasticity. J Neurophysiol 79:3216-3228.

Scheuner D, Eckman C, Jensen M, Song X, Citron M, Suzuki N, Bird TD, Hardy J, Hutton M, Kukull W, Larson E, Levy-Lahad E, Viitanen M, Peskind E, Poorkaj P, Schellenberg G, Tanzi R, Wasco W, Lannfelt L, Selkoe D, Younkin S (1996) Secreted amyloid beta-protein similar to that in the senile plaques of Alzheimer's disease is increased in vivo by the presenilin 1 and 2 and APP mutations linked to familial Alzheimer's disease. Nature Med 2:864-870.

Selkoe DJ (1994) Amyloid beta-protein precursor: new clues to the genesis of Alzheimer's disease. Curr Opin Neurobiol 4:708-716.

Semenenko FM, Bramwell S, Sidebottom E, Cuello AC (1985) Development of a mouse antiperoxidase secreting hybridoma for use in the production of a mouse PAP complex for immunocytochemistry and as a parent cell line in the development of hybrid hybridomas. Histochemistry $83: 405-408$.

Shen J, Bronson RT, Chen DF, Xia W, Selkoe DJ, Tonegawa S (1997) Skeletal and CNS defects in Presenilin-1-deficient mice. Cell 89:629-639.

Sherrington R, Rogaev EI, Liang Y, Rogaeva EA, Levesque G, Ikeda M, Chi H, Lin C, Li G, Holman K (1995) Cloning of a gene bearing missense mutations in early-onset familial Alzheimer's disease. Nature 375:754-760.

Sofroniew MV, Pearson RC, Eckenstein F, Cuello AC, Powell TP (1983) Retrograde changes in cholinergic neurons in the basal forebrain of the rat following cortical damage. Brain Res 289:370-374.

Sturchler-Pierrat C, Abramowski D, Duke M, Wiederhold KH, Mistl C, Rothacher S, Ledermann B, Burki K, Frey P, Paganetti PA, Waridel C, Calhoun ME, Jucker M, Probst A, Staufenbiel M, Sommer B (1997) Two amyloid precursor protein transgenic mouse models with Alzheimer disease-like pathology. Proc Natl Acad Sci USA 94:13287-13292.

Suzuki N, Cheung TT, Cai XD, Odaka A, Otvos LJ, Eckman C, Golde TE, Younkin SG (1994) An increased percentage of long amyloid beta protein secreted by familial amyloid beta protein precursor (beta APP717) mutants. Science 264:1336-1340.

Tang Y, Mishkin M, Aigner TG (1997) Effects of muscarinic blockade in perirhinal cortex during visual recognition. Proc Natl Acad Sci USA 94:12667-12669.

Whitehouse PJ, Price DL, Struble RG, Clark AW, Coyle JT, Delon MR (1982) Alzheimer's disease and senile dementia: loss of neurons in the basal forebrain. Science 215:1237-1239.

Winkler J, Suhr ST, Gage FH, Thal LJ, Fisher LJ (1995) Essential role of neocortical acetylcholine in spatial memory. Nature 375:484-487.

Wong PC, Zheng H, Chen H, Becher MW, Sirinathsinghji DJ, Trumbauer ME, Chen HY, Price DL, Van der Ploeg LH, Sisodia SS (1997) Presenilin 1 is required for Notch1 and DII1 expression in the paraxial mesoderm. Nature 387:288-292.

Wong TP, Campbell PM, Ribeiro-da-Silva A, Cuello AC (1998) Synaptic numbers across cortical laminae and cognitive performance of the rat during ageing. Neuroscience 84:403-412. 